\title{
Pemilihan Alternatif Bahan Bakar Mesin Pembangkit PLTD Menggunakan Metode Value Engineering
}

\author{
Billy J. Camerling ${ }^{1, *}$, R. A. de Fretes ${ }^{2}$ \\ Email: camerlingbilly@gmail.com ; de_bell89@yahoo.com \\ ${ }^{1}$ Jurusan, Teknik Industri, Universitas Pattimura, Kampus Poka, Ambon, 97233, Indonesia \\ *Email: camerlingbilly@gmail.com ; de_bell89@yahoo.com \\ 2 Jurusan, Teknik Industri, Universitas Pattimura, Kampus Poka, Ambon, 97233, Indonesia \\ "Email: rdefretes@yahoo.com
}

\begin{abstract}
ABSTRAK
Pusat Listrik Tenaga Diesel (PLTD) adalah pembangkit listrik yang menggunakan mesin diesel berbahan bakar High Speed Diesel (HSD) atau solar. Dengan digunakannya bahan bakar konvensional selain dilihat dari sisi kadar polusi pada gas buang kemungkinan pembangkit ini sulit untuk dioperasikan di masa mendatang dikarenakan persediaan minyak bumi dunia yang semakin menipis. Selain itu pasar minyak dunia yang tidak stabil menjadikan bahan bakar utama PLTD ini semakin mahal. Padahal di sisi lain, PLN dipaksa untuk menjual energi listrik dengan harga yang murah dan ramah lingkungan. Apabila hal ini tidak diantisipasi maka PLN akan mengalami kerugian serta mendapat label sebagai perusahaan yang tidak ramah lingkungan. Saat ini PLTD Namlea dihadapkan terhadap lima pilihan alternatif bahan bakar. Penelitian ini mencoba untuk menganalisa keputusan pemilihan alternatif bahan bakar menggunakan metode Value Engineering sehingga bahan bakar terpilih merupakan alternatif bahan bakar terbaik yang digunakan PLN khususnya PLTD Namlea dalam proses produksi energi listrik. Dari ke lima pilihan alternatif bahan bakar tersebut, alternatif bahan bakar terpilih adalah alternatif ke 4 yaitu Penggunaan Bio Solar (B20) + Thermol D yang memiliki performansi 58.2249387440 dan value 1.13270657 atau lebih unggul dari alternatif awal (Campuran HSD dan Bio Solar) serta terbukti dapat menurunkan biaya pokok produksi sebesar Rp. 54,- per kWh dan subsidi pemerintah sebesar Rp. 1.229,- per kWh dari alternatif awal yang sedang digunakan saat ini.
\end{abstract}

Kata Kunci : Keputusan, Performansi, Value, Value Engineering

\section{PENDAHULUAN}

Pembangkit Listrik Tenaga Diesel (PLTD) adalah pembangkit listrik yang menggunakan mesin diesel berbahan bakar High Speed Diesel (HSD) atau solar sebagai penggerak mula (prime mover). Prime mover merupakan peralatan yang berfungsi menghasilkan energi mekanis untuk memutar rotor generator sehingga energi listrik dapat diproduksi. Keuntungan utama penggunaan pembangkit listrik tenaga diesel adalah praktis untuk dibangun pada kondisi geografis kepulauan seperti Maluku dan dapat beroperasi sepanjang waktu selama masih tersedianya bahan bakar. PLTD biasanya digunakan untuk memenuhi kebutuhan listrik dalam jumlah beban kecil, terutama untuk daerah baru yang terpencil atau untuk listrik pedesaan dan untuk memasok kebutuhan listrik suatu pabrik. Keandalan pembangkit ini tinggi karena dalam operasinya tidak bergantung pada alam seperti halnya PLTA. Mengingat waktu startnya yang cepat namun ongkos bahan bakarnya tergolong mahal dan bergantung dengan perubahan harga minyak dunia yang cenderung meningkat dari tahun ke tahun, PLTD disarankan hanya dipakai untuk melayani konsumen pada saat beban puncak. Dengan digunakannya bahan bakar konvensional maka adanya kemungkinan pembangkit ini akan sulit dioperasikan di masa depan karena persediaan minyak bumi dunia yang semakin menipis. Harga minyak yang terus meningkat menjadi pertimbangan utama dalam menggunakan pembangkit ini. Padahal di sisi lain, PLN dipaksa untuk menjual energi listrik dengan harga yang murah. Apabila hal ini tidak diantisipasi maka PLN akan mengalami kerugian.
Bulan Juni 2016 merupakan bulan dimana operasional penggunaan solar atau HSD digantikan dengan Bio Solar (B20) sebagai bahan bakar utama pada mesin PLTD Namlea sesuai dengan kebijakan pemerintah. Bio Solar merupakan bahan bakar alternatif bersifat renewable energy yang diformulasikan khusus untuk mesin diesel. Bio Solar terbuat dari pengolahan minyak nabati. Untuk saat ini, PLTD Namlea sendiri belum sepenuhnya menggunakan Bio Solar, karena keterbatasan pasokan Bio Solar (B20) dari suplier. Keuntungan penggunaan bahan bakar Bio Solar (B20) antara lain merupakan energi baru-terbarukan (renewable energy), ramah lingkungan, proses pembakaran lebih sempurna, harga pokok produksi lebih rendah dari bahan bakar solar, mengurangi subsidi pemerintah untuk pembiayaan energi listrik, dan mengurangi impor solar.

Namun setelah berjalan kurang lebih enam bulan, dari data yang telah dikumpulkan didapati bahwa nilai SFC keseluruhan di PLTD Namlea justru meningkat. SFC (Specific Fuel Consumption) adalah ukuran efisiensi suatu mesin diesel yang menggambarkan rasio antara jumlah pemakaian bahan bakar dan energi listrik yang dihasilkan. Semakin kecil nilai SFC suatu mesin maka menunjukkan mesin tersebut semakin efisien. SFC merupakan salah satu komponen target penilaian yang sangat berpengaruh terhadap kinerja suatu sistem pembangkit diesel. Dari masalah ini munculah empat alternatif bahan bakar baru terhadap alternatif awal dimana diharapkan dari alternatif-alternatif baru tersebut salah satunya dapat memberikan hasil yang lebih baik dibandingkan 
dengan alternatif awal. PLTD Namlea dituntut untuk memilih dan menentukan satu diantara kelima alternatif tersebut untuk dijadikan bahan bakar utama produksi energi listrik. Maka dari itu perlu dilakukan suatu analisis keputusan pemilihan alternatif bahan bakar sebagai jawaban pemilihan alternatif bahan bakar terbaik untuk produksi energi listrik di PLTD Namlea. Selain itu diharapkan PLTD Namlea dapat mengetahui performansi dan nilai lebih dari alternatif terpilih terhadap alternatif awal yang sedang digunakan saat ini. Masalah pendistribusian suatu produk bagi suatu perusahaan merupakan salah satu masalah yang sangat penting. Dengan maksud bahwa semakin luas wilayah pemasaran, maka kendala yang dihadapai semakin banyak pula. Oleh karena itu perlu ada kebijakankebijakan khususnya tentang pembagian wilayah pemasaran pada masing-masing wilayah. Kebijakan ini membutuhkan penempatan persediaan pada setiap lokasi. Penyimpanan persediaan transit ini perlu ditangani dengan baik agar persedian yang ada dapat optimal, artinya dapat memenuhi tuntutan permintaan yang ada, tanpa harus melakukan penyimpanan yang berlebihan sehingga dapat menumpuk di gudang. Hal ini bisa menyebabkan tingginya biaya penyimpanan dan kemungkinan kerusakan yang terjadi semakin besar.

\section{Perumusan Masalah}

Berdasarkan uraian latar belakang diatas, maka dapat rumusan masalah yaitu Alternatif bahan bakar apa yang harus dipilih dalam proses produksi energi listrik di PLTD Namlea.

\section{Tujuan Penelitian}

Penelitian ini dibuat dengan tujuan untuk menganalisa pemilihan bahan bakar utama yang akan digunakan. Tujuan penelitian ini kemudian diuraikan ke dalam beberapa tujuan penelitian sebagai berikut :

1. Menentukan alternatif bahan bakar terbaik dalam proses produksi energi listrik di PLTD Namlea.

2. Mengetahui perbandingan Biaya Pokok Produksi energi listrik PLN pada penggunaan alternatif bahan bakar terpilih terhadap alternatif awal.

3. Mengetahui perbandingan jumlah subsidi pemerintah pada penggunaan alternatif bahan bakar terpilih terhadap alternatif awal.

4. Mengetahui perbandingan performansi dan value pada penggunaan alternatif bahan bakar terpilih terhadap alternatif awal.

\section{KAJIAN TEORI DAN METODE}

\section{Potensi Bio Solar Di Indonesia}

Bio Solar merupakan bahan bakar minyak yang dapat diperbaharui. Bahan bakar minyak ini berasal dari bahan baku yang dapat diperbaharui seperti tumbuhan dan hewan. Bahan bakar minyak ini merupakan hasil proses esterifikasi dan transesterifikasi. Produksi minyak setiap jenis bahan baku berbeda-beda menurut jenisnya. Enam jenis bahan baku yang berpotensi sebagai suplemen bahan bakar motor diesel di Indonesia yaitu minyak jelantah, kelapa sawit, kelapa, alga, jarak pagar dan karet. Besar potensi produksi minyak Bio Solar dari enam jenis bahan baku Bio Solar meliputi jarak pagar 557.842 barel minyak
Bio Solar. Disusul dengan kelapa sawit 438.876 barel, alga 258.867 barel, kelapa 238.455 barel, minyak jelantah 45.515 barel, dan karet 3.989,7 barel. Dengan adanya suplemen Bio Solar, Indonesia akan dapat mengatasi krisis energi sampai pada tahun 2101 . Berikut ini tabel produksi minyak nabati per hektar [9]:

Tabel. 1 Produksi Minyak Nabati per Hektar

\begin{tabular}{|l|c|l|c|}
\hline \multicolumn{1}{|c|}{ Tanaman } & Kg/Ha & \multicolumn{1}{c|}{ Tanaman } & Kg/Ha \\
\hline Jagung & 145 & Jarak & 790 \\
\hline Mete & 148 & Bunga Matahari & 800 \\
\hline Sandum & 183 & Coklat & 863 \\
\hline Lupine & 189 & Kacang & 690 \\
\hline Biji Karet & 195 & Bunga Candu & 978 \\
\hline Kenaf & 217 & Biji Raps & 1000 \\
\hline Calenduna & 230 & Zaitun & 1019 \\
\hline Kapas & 273 & Glassava & 1112 \\
\hline Rami & 305 & Biji Jarak & 1119 \\
\hline Kacamg Hijau & 375 & Bacuri & 1188 \\
\hline Kopi & 388 & Pecan & 1197 \\
\hline Biji Rami & 402 & Mentimun & 1505 \\
\hline Hazelnut & 405 & Babasau Palm & 1528 \\
\hline Euphorbia & 440 & Jarak Pagar & 1541 \\
\hline Biji Labu & 449 & Mecadamia Nut & 1887 \\
\hline Ketumbar & 450 & Kacang Brasil & 2010 \\
\hline Mustard & 481 & Alpukat & 2217 \\
\hline Camelina & 490 & Kelapa & 2260 \\
\hline Wijen & 585 & Oiticia & 2520 \\
\hline Crambe & 589 & Buriti Palm & 2743 \\
\hline Safflower & 655 & Pequi & 3142 \\
\hline Labu & 665 & Macauba Palm & 3775 \\
\hline Padi & 696 & sawit & 5000 \\
\hline
\end{tabular}

\section{Konsep Rekayasa Nilai.}

"Rekayasa nilai adalah suatu teknik manajemen yang menggunakan pendekatan sistematis untuk mencapai keseimbangan fungsional antara biaya, keandalan dan performansi dari suatu produk atau proyek "(Larry W.

\section{Zimmerman dan Glen D.Hard).}

"Rekayasa Nilai merupakan suatu teknik manajemen yang menggunakan pendekatan sistematis untuk mencapai keseimbangan fungsional yang terbaik antara biaya,keandalan dan penampilan dari suatu sistem atau produk"(Zimmerman and Hart,Value Engineering : A Practical Approach for Owners, Designers and Contractors, Hal 2)

Dari definisi-definisi tersebut di atas, terlihat bahwa konsep Rekayasa Nilai adalah penekanan pada biaya proyek atau produk dengan tanpa menurunkan kualitas. Karakteristik Rekayasa Nilai adalah sebagai berikut :

1. Berorientasi pada sistim, yang artinya melihat suatu produk atau proyek secara menyeluruh dengan melihat keterkaitan antar komponen dan memperhatikan fungsi dan nilai dari masing-masing komponen yang terlibat.

2. Bersifat multi disiplin, yang dilakukan oleh beberapa ahli yang berkompeten dan berpengalaman dibidangnya.

3. Merupakan suatu teknik manajemen yang diaplikasikan untuk mencari efisiensi biaya proyek atau produk tanpa mengorbankan mutu, keandalan dan performansi.

4. Berorientasi pada fungsi, artinya berusaha memenuhi fungsi-fungsi yang diperlukan dan sebanding dengan nilai yang diperoleh.

Berdasarkan prinsip dasar Rekayasa Nilai, tujuan utama perancangan produk adalah untuk memenuhi kebutuhan dan memberikan kepuasan kepada pemakai 
produk. Oleh karena itu, para perancang seharusnya tidak memberikan fungsi-fungsi pada produk secara berlebihan, karena hal ini akan mengakibatkan penambahan biaya. Dengan demikian, tujuan Rekayasa Nilai adalah untuk mendapatkan nilai (Value) semaksimal mungkin.

Secara sederhana, nilai dapat dicari dengan menggunakan rumus :

$$
\begin{aligned}
\mathbf{V}= & \frac{\mathrm{P}}{\mathrm{C}} \\
\text { Dimana: } \mathrm{V} & =\text { Nilai } \\
\mathrm{P} & =\text { Performance } \\
\mathrm{C} & =\text { Biaya }
\end{aligned}
$$

Persamaan di atas menunjukan ukuran dari suatu keberhasilan dalam suatu desain. Nilai dinyatakan sebagai perbandingan antara performansi atau fungsi yang diberikan oleh sistim yang sedang didesain dengan jumlah biaya untuk mengadakan fungsi-fungsi atau performansi yang diberikan oleh fungsi. [4]

\section{Alternatif Fungsi}

Setelah biaya total dan biaya yang diperlukan untuk memenuhi fungsi primer dan fungsi sekunder, maka dapat ditampilkan alternatif baru dengan biaya baru, kemudian alternatif lama dan alternatif baru tersebut dibandingkan, dengan maksud agar supaya alternatif mana yang mempunyai nilai tertinggilah yang akan dipilih. Di dalam Rekayasa Nilai, diperlukan kreatifitas yang tinggi, hal ini disebabkan karena kreatifitas dari seseorang merupakan hal yang sangat menunjang dalam suatu studi Rekayasa Nilai. Semua ide-ide serta alternatif-alternatif yang ada harus ditampilkan sebanyak mungkin dan dianalisa untuk mencari aternatif yang terbaik. Untuk memunculkan ide-ide, dalam Rekayasa Nilai dilakukan dengan cara sumbang saran (Brainstorming) antara anggota tim atau orang yang terlibat langsung (berpengalaman) pada suatu disiplin ilmu tertentu.

\section{Menguji Konsistensi Data}

Konsistensi data didapat dari Rasio Konsistensi (CR) yang merupakan hasil bagi antara Indeks Konsistensi (CI) dan indeks Random (RI).

$$
\mathbf{C R}=\frac{C I}{R I}
$$

Untuk mendapatkan nilai indeks konsistensi (CI) akan digunakan rumus :

$$
\mathrm{CI}=\frac{\left(\sum_{K-1}^{N} \lambda \max \right)-n}{n-1}
$$

dimana: $\mathrm{CI}=$ Indeks konsistensi

$$
\mathrm{n} \quad=\text { Banyaknya elemen atau kriter }
$$

$\lambda$ Maks = Nilai eugenvalue

Indeks konsistensi diperoleh dengan mengurangkan eugenvalue maksimum terhadap $n$ (jumlah elemen) dan membaginya dengan $(\mathrm{n}-1)$, sedangkan rasio indeks diperoleh dari tabel. Data dapat dikatakan konisten, jika nilai Rasio Konsistensi (CR) < 0,100

Teknik Pengukuran Data.
Cara pengukuran data di sini mempunyai hubungan satu dengan lainnya dan bertujuan adalah untuk mencapai sasaran yang diinginkan. Setiap sampel yang diukur biasanya dibagi dalam beberapa variabel.

Pengukuran Menurut Skala Likert.

Prinsip pengukuran ini adalah semakin banyak jumlah pilihan atau alternatif yang diambil, maka akan semakin khusus pembagiannya, tetapi semakin sedikit jumlah pilihan atau alternatif, maka akan semakin umum materi pembagiannya. Pengukuran ini mulamula diciptakan oleh Rensis Likert pada tahun 1932. Pengukuran Dengan Skala Pembobotan

Pengukuran dengan skala pembobotan ini dilakukan dengan jalan memberikan kebebasan kepada responden untuk melakukan penilaian. Penilaian yang dilakukan adalah dengan memilih atau mengurutkan variabel-variabel yang menjadi kebutuhan menurut urutan prioritas yang dikehendaki. Urutan prioritas dinyatakan dengan nomor urut 1 mendapat nilai 10 , nomor urut 2 mendapat nilai 9 dan seterusnya.

\section{Prinsip Dasar Value Engineering}

Penelitian ini dilaksanakan melalui beberapa tahap, yaitu :

1. Studi Pendahuluan

Studi pendahuluan diperlukan guna meneliti lebih lanjut apa yang akan menjadi permasalahan dalam penelitian. Studi pendahuluan terdiri dari studi literature dan pengamatan langsung di lapangan.

2. Perumusan Masalah dan Tujuan Penelitian

Hasil studi pendahuluan dianalisis untuk menentukan masalah utama yang dipilih sebagai masalah penelitian. Selanjutnya, ditetapkan tujuan penelitian untuk mengarahkan semua aktivitas dalam kegiatan penelitian, termasuk pengumpulan data dan analisis.

3. Studi Pustaka

Kegiatan ini dilakukan untuk menelusuri konsepkonsep teoritis yang relevan dengan masalah penelitian dan sekaligus untuk mengetahui data, metode pengumpulan data dan metode analisis yang tepat dalam menyelesaikan permasalahan penelitian tersebut.

4. Pengumpulan Data

Pada tahap ini dilakukan dengan pemberian kuisioner, serta perhitungan menggunakan metode AHP (Analytical Hierarchy Process) sebagai acuan analisis selanjutnya.

5. Analisa Data

Data yang telah dikumpulkan selanjutnya diolah dan diintrepretasikan untuk menjawab tujuan penelitian. Pada tahap ini digunakan metode Value Engineering [8]. Hasil dari pengolahan data dianalisa dan dievaluasi menggunakan metoda Value Engineering untuk mengetahui jenis bahan bakar terbaik yang akan digunakan.

Tahapan Value Engineering antara lain adalah :
a) Penentuan Kriteria
b) Penentuan Tingkat Prioritas
c) Penentuan Tingkat Kepentingan Kriteria
d) Pembuatan Tabel Keuntungan Kerugian
e) Pembuatan Matrik Kelayakan 
f) Pembuatan Matrik Evaluasi

g) Perhitungan Pembobotan Kriteria

h) Perhitungan Performansi

i) Pembuatan Tabel Biaya

j) Perhitungan Value

k) Penentuan Keputusan

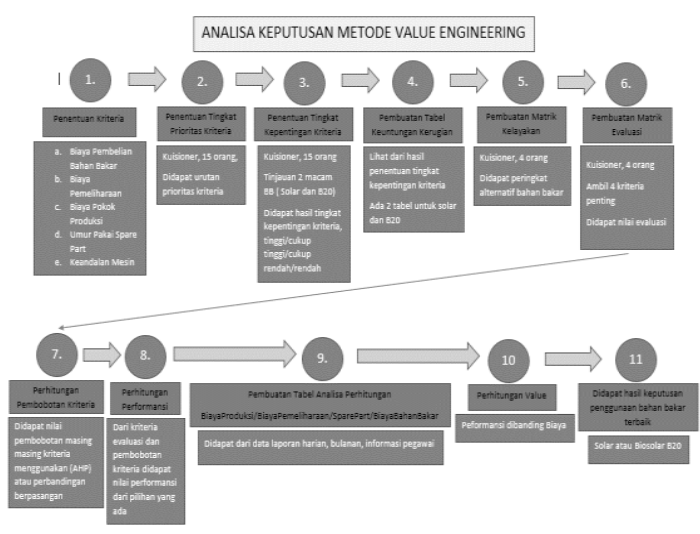

Gambar 1 Alur Tahapan Value Engineering

6. Kesimpulan dan Saran

Hasil pengolahan dan analisis data kemudian disimpulkan dengan memperhatikan tujuan penelitian. Disamping itu, juga diberikan saran yang berkaitan dengan penggunaan/penerapan hasil penelitian.

Tahapan proses penelitian dapat dilihat pada gambar di bawah.

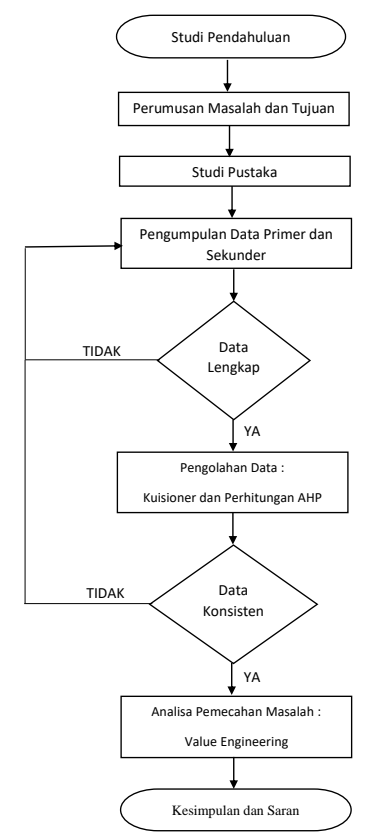

Gambar 2 Diagram Alir Penelitian

\section{Hasil dan Pembahasan}

Hasil perhitungan performansi untuk alternatif awal dan alternatif yang diusulkan adalah sebagai berikut :
Tabel 1 Hasil Perhitungan Performansi

\begin{tabular}{|c|c|c|c|c|c|c|c|}
\hline \multirow{3}{*}{ Alternatif } & & & teria Eval & & & \multirow{3}{*}{$\mathrm{Pn}$} & \multirow{3}{*}{ Rankin } \\
\hline & 1 & 2 & 3 & 4 & 5 & & \\
\hline & \multicolumn{5}{|c|}{ Bobot Tiap - tiap } & & \\
\hline Awal (Mix HSD & 0,2819 & 0,1729 & 0,1131 & 0,0756 & 0,3562 & & \\
\hline $\begin{array}{l}+ \text { Biosolar) } \\
\end{array}$ & 56 & 45 & 46 & 44 & 57 & 52,413899 & 3 \\
\hline 1 (HSD) & 59 & 42 & 50 & 42 & 43 & 48,054486 & 5 \\
\hline $\begin{array}{l}2 \text { (Biosolar } \\
\text { B20) }\end{array}$ & 51 & 52 & 40 & 47 & 59 & 52,475430 & 2 \\
\hline $\begin{array}{l}\text { (HSD + } \\
\text { Thermol D) } \\
\end{array}$ & 65 & 50 & 56 & 42 & 43 & 51,808999 & 4 \\
\hline $\begin{array}{l}4 \text { (Biosolar B20 } \\
+ \text { Thermol D) }\end{array}$ & 70 & 51 & 45 & 47 & 59 & 58,224938 & 1 \\
\hline
\end{tabular}

Keterangan :

Kriteria 1 adalah Biaya Pokok Produksi

Kriteria 2 adalah Biaya Pembelian Bahan Bakar

Kriteria 3 adalah Umur Pakai Spare Part

Kriteria 4 adalah Ramah Lingkungan

Kriteria 5 adalah Penggunaan Energi Baru Terbarukan

Tabel 2 Tabel kWh Produksi, BBM, SFC,dan BPP 1

\begin{tabular}{|c|c|c|c|c|c|c|c|c|}
\hline \multirow[b]{2}{*}{$\begin{array}{l}\text { Jenis } \\
\text { BBM }\end{array}$} & \multirow[b]{2}{*}{ ket. } & \multicolumn{6}{|c|}{$\begin{array}{l}\text { Bulan } \\
\end{array}$} & \multirow{2}{*}{$\begin{array}{l}\text { Total Rata } \\
\text { rata Juni- } \\
\text { Novemer } \\
1\end{array}$} \\
\hline & & Juni & Juli & Agustus & $\begin{array}{c}\begin{array}{c}\text { Septemb } \\
\text { er }\end{array} \\
\end{array}$ & Oktober & $\begin{array}{c}\begin{array}{c}\text { Novemb } \\
\text { er }\end{array} \\
\end{array}$ & \\
\hline $\begin{array}{l}\mathrm{MX} / \mathrm{HSD} \\
\mathbf{B z 2 0}\end{array}$ & $\begin{array}{l}\text { kWh } \\
\text { Produksi }\end{array}$ & $2.364,97$ & $\begin{array}{l}2.275,66 \\
2\end{array}$ & $\begin{array}{l}2.389,22 \\
3\end{array}$ & $\begin{array}{l}2.375,60 \\
0\end{array}$ & $\begin{array}{l}2,546,44 \\
3\end{array}$ & $2.580,85$ & $2.422,127$ \\
\hline HSD & \multirow{3}{*}{$\begin{array}{c}\begin{array}{c}\mathrm{SFC} \\
(\text { (Liter } / \mathrm{kW} \\
\text { h) }\end{array} \\
\end{array}$} & 0,267 & 0,267 & 0,268 & 0,271 & 0,274 & 0,258 & 0,268 \\
\hline 820 & & 0,267 & 0,269 & 0,268 & 0,266 & 0,271 & 0,270 & 0,269 \\
\hline$M X$ & & 0,267 & 0,268 & 0,268 & 0,268 & 0,272 & 0,270 & 0,269 \\
\hline HSD & \multirow{3}{*}{$\begin{array}{l}\text { Harga } \\
\text { BBM } \\
\text { (Liter) }\end{array}$} & $\begin{array}{c}\text { Rp. } \\
5.646\end{array}$ & \begin{tabular}{|c|} 
Rp. \\
5.558
\end{tabular} & $\begin{array}{l}\text { Rp. } \\
5655\end{array}$ & $\begin{array}{c}\text { Rp. } \\
5.061\end{array}$ & $\begin{array}{l}\text { Rp. } \\
\text { Rp. } \\
5405\end{array}$ & $\begin{array}{l}\text { Rp. } \\
5.463\end{array}$ & Rp. 5.513 \\
\hline 820 & & 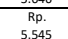 & $\begin{array}{c}.030 . \\
\text { Rp. } \\
5.563\end{array}$ & $\begin{array}{c}.050 . \\
5.576 \\
5.56\end{array}$ & $\begin{array}{c}.001 \\
5.134 \\
5.134\end{array}$ & $\begin{array}{c}.40 \mathrm{~s} \\
\text { R. } \\
5.481\end{array}$ & $\begin{array}{c}.045 . \\
\text { Rp. } \\
5.718\end{array}$ & Rp. 5.503 \\
\hline$M X$ & & $\begin{array}{c}\text { Rp. } \\
5.596\end{array}$ & $\begin{array}{c}\text { Rp. } \\
5.611\end{array}$ & $\begin{array}{c}\text { Rp. } \\
5.621\end{array}$ & $\begin{array}{c}\text { Rp. } \\
5.098\end{array}$ & $\begin{array}{c}\text { Rp. } \\
5.443\end{array}$ & $\begin{array}{c}\text { Rp. } \\
5.681\end{array}$ & Rp. 5.508 \\
\hline MX & $\begin{array}{c}\text { Total } \\
\text { biaya } \\
\text { (Rupiah) }\end{array}$ & $\begin{array}{c}\text { Rp. } \\
3.533 .04 \\
0,48\end{array}$ & $\begin{array}{c}\mathrm{Rp} . \\
3.423 .72 \\
3,11 \\
\end{array}$ & $\begin{array}{c}\text { Rp. } \\
3.595 .18 \\
9,28 \\
\end{array}$ & $\begin{array}{c}\text { Rp. } \\
3.250 .53 \\
4.50 \\
\end{array}$ & $\begin{array}{c}\text { Rp. } \\
3.763 .96 \\
0,30\end{array}$ & $\begin{array}{c}\text { Rp. } \\
3.960 .47 \\
0,55\end{array}$ & $\begin{array}{c}\text { Rp. } \\
3.587 .819 . \\
706,8 \\
\end{array}$ \\
\hline HSD & \multirow{2}{*}{$\begin{array}{l}\text { Total } \\
\text { biaya bila } \\
100 \% \\
\text { HSDD/820 } \\
\text { (Rupiah) }\end{array}$} & $\begin{array}{c}\text { Rp. } \\
3.565 .17 \\
6,20\end{array}$ & $\begin{array}{c}\text { Rp. } \\
3.433 .21 \\
7,69\end{array}$ & $\begin{array}{c}\text { Rp. } \\
3.73273 \\
4,67\end{array}$ & $\begin{array}{c}\text { Rp. } \\
3.254 .23 \\
5,57\end{array}$ & $\begin{array}{c}\text { Rp. } \\
3.767 .68 \\
0,61\end{array}$ & $\begin{array}{c}\text { Rp. } \\
3.755 .05 \\
8,14\end{array}$ & $\begin{array}{c}\text { Rp. } \\
3.567 .183 . \\
817,3\end{array}$ \\
\hline 820 & & $\begin{array}{c}\text { Rp. } \\
3.500 .57 \\
2,48\end{array}$ & $\begin{array}{c}\mathrm{Rp} . \\
3.401 .87 \\
8,16\end{array}$ & $\begin{array}{c}\text { Rp. } \\
3.565 .15 \\
0,84\end{array}$ & $\begin{array}{c}\text { Rp. } \\
3.249 .56 \\
5,79\end{array}$ & $\begin{array}{c}\text { Rp. } \\
3.789 .20 \\
2,82\end{array}$ & $\begin{array}{c}\mathrm{Rp} . \\
3.986 .82 \\
9,99\end{array}$ & $\begin{array}{c}\text { Rp. } \\
3.582 .200 . \\
017,2\end{array}$ \\
\hline HSD & \multirow{3}{*}{$\begin{array}{c}\text { Bpp } \\
\text { Bahan } \\
\text { bakar } \\
\text { (Raupiah/ } \\
\text { kWh) }\end{array}$} & $\begin{array}{c}\mathrm{Rp} . \\
1.507,49\end{array}$ & $\begin{array}{c}\mathrm{Rp} . \\
1.508,67\end{array}$ & $\begin{array}{c}\text { Rp. } \\
1.518,37\end{array}$ & $\begin{array}{c}\text { Rp. } \\
1.369,86\end{array}$ & $\begin{array}{c}\mathrm{Rp} . \\
1.479,59\end{array}$ & $\begin{array}{c}\mathrm{Rp} . \\
1.454,96\end{array}$ & $\begin{array}{c}\text { Rp. } \\
1.472,88\end{array}$ \\
\hline B20 & & $\begin{array}{c}\mathrm{Rp} \\
1.480,17\end{array}$ & 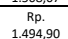 & $\begin{array}{c}\text { Rp. } \\
1.492,18\end{array}$ & $\begin{array}{c}\text { Rp } \\
1.367 .89\end{array}$ & $\begin{array}{c}R p \\
\text { Rp } \\
1.488,04\end{array}$ & $\begin{array}{c}\text { Rp } \\
1.544,77\end{array}$ & $\begin{array}{c}\text { Rp } \\
1.488,80\end{array}$ \\
\hline MX & & $\begin{array}{c}\mathrm{Rp} \\
1.493,90\end{array}$ & $\begin{array}{c}\text { Rp. } 1 \\
504,50\end{array}$ & $\begin{array}{c}\mathrm{Rp} \\
1.504,75\end{array}$ & $\begin{array}{c}\text { Rp } \\
1.368,30\end{array}$ & $\begin{array}{c}\mathrm{Rp} \\
1.478,12\end{array}$ & $\begin{array}{c}\text { Rp } \\
1.534,56\end{array}$ & $\begin{array}{c}\mathrm{Rp} \\
1.481,27\end{array}$ \\
\hline HSD & \multirow{3}{*}{$\begin{array}{c}\text { BPP } \\
\text { (Rupiah/ } \\
\text { kWh) }\end{array}$} & $\begin{array}{c}\mathrm{Rp} \\
2.804,40\end{array}$ & $\begin{array}{c}\text { Rp. } \\
2.856,48\end{array}$ & $\begin{array}{c}\mathrm{Rp} . \\
2.802,13\end{array}$ & $\begin{array}{c}\mathrm{Rp}^{\mathrm{R}} \\
2.660,97\end{array}$ & $\begin{array}{c}\mathrm{Rp} . \\
2.684,08\end{array}$ & $\begin{array}{c}\text { Rp. } \\
2.643,39\end{array}$ & $\begin{array}{c}\mathrm{Rp} . \\
2.741,91\end{array}$ \\
\hline 820 & & $\begin{array}{c}\text { Rp. } \\
2.777,09\end{array}$ & $\begin{array}{c}\mathrm{Rp} . \\
2.842,71\end{array}$ & $\begin{array}{c}\mathrm{Rp} . \\
2.775,93\end{array}$ & $\begin{array}{c}\text { Rp. } \\
2.659,00\end{array}$ & $\begin{array}{c}\begin{array}{c}\text { Rp. } \\
2.692,53\end{array} \\
\end{array}$ & $\begin{array}{c}\text { Rp. } \\
2.733,20\end{array}$ & $\begin{array}{c}\text { Rp. } \\
2.746,74\end{array}$ \\
\hline MX & & $\begin{array}{c}\mathrm{Rp} \\
2.790,81\end{array}$ & $\begin{array}{c}\text { Rp } \\
2.852,31\end{array}$ & $\begin{array}{c}\mathrm{Rp} \\
2.788,50\end{array}$ & $\begin{array}{c}R p \\
2.659,41\end{array}$ & $\begin{array}{c}\text { Rp } \\
2.682,62\end{array}$ & $\begin{array}{c}\text { Rp } \\
2.722,98\end{array}$ & $\begin{array}{c}\text { Rp } \\
2.749,44\end{array}$ \\
\hline
\end{tabular}

Tabel 3 Tabel kWh Produksi, BBM, SFC,dan BPP 2

\begin{tabular}{|c|c|c|c|c|c|c|c|c|}
\hline \multirow{2}{*}{$\begin{array}{l}\text { Jenis } \\
\text { BBM }\end{array}$} & \multirow[b]{2}{*}{ Ket. } & \multicolumn{6}{|c|}{ Bulan } & \multirow{2}{*}{$\begin{array}{l}\text { Total Rata- } \\
\text { rata (unni- } \\
\text { November) } \\
\end{array}$} \\
\hline & & Juni & Juli & Agustus & $\begin{array}{c}\text { Septemb } \\
\text { er }\end{array}$ & Oktober & $\begin{array}{c}\text { Novemb } \\
\text { er }\end{array}$ & \\
\hline $\begin{array}{l}\mathrm{HSDD} / \\
\mathrm{B} 20\end{array}$ & $\begin{array}{l}\text { kWh } \\
\text { Produksi }\end{array}$ & 2.364,97 & $2.275,66$ & $2.389,22$ & $2.375,60$ & $2.546,44$ & $2.580,85$ & $2.422,12$ \\
\hline TSD+ & \multirow{2}{*}{$\begin{array}{c}\mathrm{SFC} \\
\text { (Liter//kW } \\
\text { h) }\end{array}$} & 0,251 & 0,251 & 0,252 & 0,254 & 0,257 & 0,242 & 0,252 \\
\hline${ }_{\mathrm{D}}^{\mathrm{B} 20+\mathrm{T}}$ & & 0,251 & 0,253 & 0,252 & 0,250 & 0,255 & 0,254 & 0,253 \\
\hline $\begin{array}{c}\text { HSD+ } \\
\text { TD }\end{array}$ & \multirow{2}{*}{$\begin{array}{l}\text { Harga } \\
\text { BBM } \\
\text { (Liter) }\end{array}$} & $\begin{array}{l}\text { Rp. } \\
\text { 5.796 }\end{array}$ & $\begin{array}{l}\text { Rp. } \\
5.808\end{array}$ & $\begin{array}{l}\text { Rp. } \\
5.815\end{array}$ & $\begin{array}{l}\text { Rp. } \\
5.211\end{array}$ & $\begin{array}{l}\text { Rp. } \\
\text { 5.555 }\end{array}$ & $\begin{array}{l}\text { Rp. } \\
\text { 5.793 }\end{array}$ & Rp. 5.663 \\
\hline $\begin{array}{c}\mathrm{B20+T} \\
\mathrm{D}\end{array}$ & & $\begin{array}{l}\mathrm{Rp} . \\
5.695\end{array}$ & $\begin{array}{l}\mathrm{Rp} . \\
5.713\end{array}$ & $\begin{array}{l}\text { Rp. } \\
5.726\end{array}$ & $\begin{array}{l}\text { Rp. } \\
5.284\end{array}$ & $\begin{array}{l}\text { Rp. } \\
5.631\end{array}$ & $\begin{array}{l}\text { Rp. } \\
5.868\end{array}$ & Rp. 5.653 \\
\hline $\begin{array}{l}\text { HSD+ } \\
\text { TD }\end{array}$ & \multirow{2}{*}{$\begin{array}{l}\text { Total } \\
\text { Biaya Bila } \\
10 \% \% \\
\text { HSD/820 } \\
\text { (Rupiah) }\end{array}$} & $\begin{array}{l}\text { Rp. } \\
3.440 .30 \\
0,32\end{array}$ & $\begin{array}{l}\text { Rp. } \\
3.312 .78 \\
2,02\end{array}$ & $\begin{array}{l}\text { Rp. } \\
3.500 .36 \\
3,72\end{array}$ & $\begin{array}{l}\text { Rp. } \\
\text { 3.149.64 } \\
4,78\end{array}$ & $\begin{array}{l}\text { Rp. } \\
\text { 3.639.90 } \\
7,09\end{array}$ & $\begin{array}{l}\text { Rp. } \\
3.623 .58 \\
1,19\end{array}$ & $\begin{array}{l}\text { Rp. } \\
3.444 .429 .8 \\
58,63\end{array}$ \\
\hline $\begin{array}{c}B 20+T \\
D\end{array}$ & & $\begin{array}{l}\text { Rp. } \\
3.379 .55 \\
1.79\end{array}$ & $\begin{array}{l}\text { Rp. } \\
3.283 .98 \\
9.59\end{array}$ & $\begin{array}{l}\text { Rp. } \\
3.441 .39 \\
3.56\end{array}$ & $\begin{array}{l}\text { Rp. } \\
3.143 .83 \\
7.80\end{array}$ & $\begin{array}{l}\text { Rp. } \\
3.659 .32 \\
8.78\end{array}$ & $\begin{array}{l}\text { Rp. } \\
3.845 .93 \\
1.32\end{array}$ & $\begin{array}{l}\text { Rp. } \\
\text { 3.459.005.4 } \\
77.64\end{array}$ \\
\hline $\begin{array}{l}\mathrm{HSD+}+ \\
\text { TD }\end{array}$ & \multirow{2}{*}{$\begin{array}{c}\text { BPp } \\
\text { Bahan } \\
\text { Bakar } \\
\text { (Rupiah/k } \\
\text { Wh) }\end{array}$} & $\begin{array}{l}\text { Rp. } \\
1.454,69\end{array}$ & $\begin{array}{l}\text { Rp. } \\
1.455,74\end{array}$ & $\begin{array}{l}\text { Rp. } \\
1.465,06\end{array}$ & $\begin{array}{l}\text { RP. } \\
1.325,83\end{array}$ & $\begin{array}{l}\text { Rp. } \\
1.429,41\end{array}$ & $\begin{array}{l}\text { Rp. } \\
1.404,02\end{array}$ & $\begin{array}{l}\mathrm{Rp} \\
1.422,64\end{array}$ \\
\hline$\frac{B 20+T}{D}$ & & $\begin{array}{l}\text { Rp. } \\
1.429,00\end{array}$ & $\begin{array}{l}\text { Rp. } \\
1.443,09\end{array}$ & $\begin{array}{l}\text { Rp. } \\
1.440,38\end{array}$ & $\begin{array}{l}\text { Rp. } \\
1.323,39\end{array}$ & $\begin{array}{l}\text { Rp. } \\
1.437,04\end{array}$ & $\begin{array}{l}\text { Rp. } \\
1.490,18\end{array}$ & $\begin{array}{l}\text { Rp. } \\
1.472,18\end{array}$ \\
\hline $\begin{array}{c}\mathrm{HSD+}+ \\
\mathrm{TD}\end{array}$ & \multirow{2}{*}{$\begin{array}{c}\text { BPP } \\
\text { (Rupiah/k } \\
\text { Wh) }\end{array}$} & $\begin{array}{l}\text { Rp. } \\
2.751,60\end{array}$ & $\begin{array}{l}\text { Rp. } \\
2.803,56\end{array}$ & $\begin{array}{l}\text { Rp. } \\
2.748,81\end{array}$ & $\begin{array}{l}\text { Rp. } \\
2.616,94\end{array}$ & $\begin{array}{l}\text { Rp. } \\
2.633,90\end{array}$ & $\begin{array}{l}\text { Rp. } \\
2.592,45\end{array}$ & $\begin{array}{l}\mathrm{Rp} . \\
2.691,21\end{array}$ \\
\hline $\begin{array}{c}\text { B20+T } \\
D\end{array}$ & & $\begin{array}{l}\mathrm{Rp} . \\
2.725,91\end{array}$ & $\begin{array}{l}\text { Rp. } \\
2.790,90\end{array}$ & $\begin{array}{l}\text { Rp. } \\
2.724,13\end{array}$ & $\begin{array}{l}\mathrm{Rp}_{2.614,50} \\
{ }_{2}\end{array}$ & $\begin{array}{l}\text { Rp. } \\
2.641,53\end{array}$ & $\begin{array}{l}\text { Rp. } \\
2.678,60 \\
\end{array}$ & $\begin{array}{l}\mathrm{Rp} . \\
2.695,93 \\
{ }_{2}\end{array}$ \\
\hline
\end{tabular}

Perhitungan nilai akan ditentukan dengan menggunakan rumus :

$$
\mathrm{V}=\mathrm{P} / \mathrm{C}
$$

Berdasarkan rumus diatas, nilai alternatif awal adalah sebesar 1, yang nantinya dapat dipakai sebagai bahan acuan untuk memilih alternatif terbaik, sehingga untuk suatu performansi dalam rupiah dihargai sebesar $n$.

Dengan asumsi bahwa alternatif bahan bakar diatas telah digunakan pada mesin pembangkit dengan ratarata operasi mesin per 30 hari adalah 20 jam, maka 
nilai (Value) alternatif awal dan alternatif terpilih dapat dilihat pada tabel berikut ini.

Tabel 4. Perhitungan Nilai (Value) Pada Kondisi Sebelum Perubahan Jenis BBM

\begin{tabular}{|c|c|c|c|c|}
\hline No. & Alternatif & Pn & Cn & Vn \\
\hline 1 & Awal (Mix HSD + Biosolar) & 52,41389980 & Rp. 2.749 & 1 \\
\hline
\end{tabular}

Tabel 5 Perhitungan Nilai (Value) Pada Kondisi Setelah Perubahan Jenis BBM

\begin{tabular}{|c|l|c|c|c|}
\hline No. & \multicolumn{1}{|c|}{ Alternatif } & Pn & Cn & Vn \\
\hline 1 & 1 (HSD) & 48,05448699 & Rp. 2.742 & 0,91916771 \\
\hline 2 & 2 (Biosolar B20) & 52,47543056 & Rp. 2.747 & 1,00190286 \\
\hline 3 & 3 (HSD + Thermol D) & 51,80899900 & Rp. 2.691 & 1,00976373 \\
\hline 4 & 4 (Biosolar B20 + Thermol D) & 58,22493874 & Rp. 2.696 & 1,13270657 \\
\hline
\end{tabular}

Berdasarkan hasil perhitungan nilai (Value) diatas, maka dapat diketahui bahwa selisih nilai dari ke empat alternatif bahan bakar dengan alternatif awal sangat kecil. Untuk itu guna menentukan pilihan terbaik dari seluruh alternatif maka perlu ditampilkan semua keuntungan dan kerugian dari tiap alternatif yaitu menyangkut besarnya pengeluaran dan subsidi pemerintah yang harus dikeluarkan bila dibandingkan terhadap alternatif awal.

Dengan asumsi semua pelanggan pengguna daya 1.300 VA dengan penetapan penyesuaian tarif tenaga listrik per kWh untuk bulan Juli - September 2017 adalah sebesar 1467,28 Rp/kWh baik untuk penggunaan listrik reguler (pasca bayar) dan penggunaan listrik pra bayar, maka besarnya pengeluaran serta subsidi yang harus dikeluarkan oleh pemerintah adalah sebagai berikut :

Tabel 6 Perhitungan Biaya Pengeluaran Dan Subsidi Sebelum Perubahan Jenis BBM

\begin{tabular}{|c|c|c|c|c|}
\hline No. & Alternatif & Pengeluaran & $\begin{array}{c}\text { BPP } \\
(\text { Liter/kWh) }\end{array}$ & $\begin{array}{c}\text { Subsidi } \\
(\mathrm{Rp} / \mathrm{kWh})\end{array}$ \\
\hline 1 & $\begin{array}{l}\text { Awal (Mix HSD } \\
+ \text { Biosolar) }\end{array}$ & $\mathrm{Rp} .39 .929 .916,419$ & $\mathrm{Rp} .2 .749,44$ & $\mathrm{Rp} . \quad 1.282$ \\
\hline
\end{tabular}

Tabel 7 Perhitungan Biaya Pengeluaran Dan Subsidi Setelah Perubahan Jenis BBM

\begin{tabular}{|c|l|c|c|c|}
\hline No. & \multicolumn{1}{|c|}{ Alternatif } & \multicolumn{1}{|c|}{ Pengeluaran } & $\begin{array}{c}\text { BPP } \\
\text { (Liter/kWh) }\end{array}$ & $\begin{array}{c}\text { Subsidi } \\
\text { (Rp/kWh) }\end{array}$ \\
\hline 1 & 1 (HSD) & Rp. $39.806 .101,082$ & Rp. $2.741,91$ & Rp. 1.275 \\
\hline 2 & 2 (Biosolar B20) & Rp. 39.896.198,282 & Rp. 2.746,74 & Rp. 1.279 \\
\hline 3 & 3(HSD + Thermol D) & Rp. $39.069 .577,330$ & Rp. 2.691,21 & Rp. 1.224 \\
\hline 4 & $\begin{array}{l}4 \text { (Biosolar B20 + } \\
\text { Thermol D) }\end{array}$ & Rp. 39.157.031,044 & Rp. 2.695,93 & Rp. 1.229 \\
\hline
\end{tabular}

Dari tabel perhitungan nilai serta tabel biaya pengeluaran dan subsidi pemerintah pada kondisi penggunaan masing-masing alternatif bahan bakar dapat dibuat suatu tabel perbandingan untung rugi, sehingga dapat dengan mudah dipilih alternatif yang terbaik.

Tabel 8 Tabel Perbandingan Untung Rugi Tiap Alternatif

\begin{tabular}{|c|c|c|c|c|c|}
\hline \multirow[b]{2}{*}{ Alternatif } & \multirow[b]{2}{*}{$\begin{array}{l}\text { Performance } \\
\quad(\mathrm{Pn})\end{array}$} & \multicolumn{2}{|c|}{ Selisih } & \multirow[b]{2}{*}{ Subsidi } & \multirow[b]{2}{*}{ Ranking } \\
\hline & & $\begin{array}{l}\text { V.Alt Awal - } \\
\text { V Alt.Pilihan }\end{array}$ & $\begin{array}{l}\text { C Alt.Awal - } \\
\text { C Alt.Pilihan } \\
\text { (Rp/Kwh) }\end{array}$ & & \\
\hline $\begin{array}{l}\text { Awal (Mix HSD } \\
+ \text { Biosolar) }\end{array}$ & 52,4138998 & - & Rp. & Rp. 1.282 & 4 \\
\hline 1 (HSD) & 48,0544869 & $-0,080832$ & $\mathrm{Rp}$. & Rp. 1.275 & 5 \\
\hline $\begin{array}{l}2 \text { (Biosolar } \\
\text { B20) }\end{array}$ & 52,4754305 & 0,001902 & Rp. & Rp. 1.279 & 3 \\
\hline $\begin{array}{l}3 \text { (HSD + } \\
\text { Thermol D) }\end{array}$ & 51,8089990 & 0,009763 & Rp. $\quad 58$ & Rp. 1.224 & 2 \\
\hline $\begin{array}{l}4 \text { (Biosolar B20 } \\
+ \text { Thermol D) }\end{array}$ & 58,2249387 & 0,132706 & Rp. & Rp. 1.229 & 1 \\
\hline
\end{tabular}

Dari tabel tersebut diatas terlihat bahwa alternatif ke 4, 3 dan 2 menjadi alternatif untuk dipilih. Dimana untuk besarnya subsidi yang harus dikeluarkan pemerintah paling sedikit alternatif 3 menempati peringkat 1 , selanjutnya alternatif 4 dan diikuti alternatif 1 . Begitu pula dari segi biaya pengeluaran (BPP) alternatif 3 menduduki peringkat 1 , selanjutnya alternatif 4 diikuti alternatif 1 . Namun dari segi performansi alternatif 4 menduduki peringkat 1 kemudian alternatif 2 lalu alternatif awal. Dari selisih valuenya terhadap alternatif awal, alternatif 4 menduduki peringkat 1 , kemudian alternatif 3 dan alternatif 2 .

Untuk mendapatkan alternatif terbaik, maka dasar pemilihan haruslah dikembalikan pada fungsi dasar bahan bakar minyak yang berkaitan dengan permasalahan yang ada. Dengan pertanyaan apakah bahan bakar yang terpilih dari ketiga alternatif tersebut merupakan pemberdayaan bahan bakar baru terbarukan sesuai instruksi pemerintah. Dari permasalahan ini jelas bahwa jenis bahan bakar yang akan digunakan pada mesin pembangkit harus terdapat upaya penggunaan bahan bakar baru terbarukan akibat dari kebijakan pemerintah saat ini. Dengan demikian maka jenis bahan bakar yang terpilih haruslah jenis bahan bakar yang sedapat mungkin menggunakan bahan bakar baru terbarukan. Berdasarkan uraian tersebut maka alternatif 4 menjadi alternatif yang terbaik untuk dipilih. Sedangkan alternatif 3 meskipun memberikan hasil yang lebih baik dari alternatif 4 dari segi biaya namun upaya dalam penggunaan bahan bakar baru terbarukan tidak terpenuhi sehingga berpengaruh terhadap jumlah performance dan valuenya. Selanjutnya untuk alternatif yang menjadi pilihan pada tahap pengembangan adalah alternatif 4 dengan pertimbangan-pertimbangan seperti di atas tersebut.

Bertitik tolak pada fungsi dasar pemilihan bahan bakar minyak mesin pembangkit diesel berdasarkan permasalahan atau isu yang ada. Dimana pemerintah mengeluarkan kebijakan pemanfaatan bahan bakar baru terbarukan di dalam proses produksi energi listrik khususnya di PLTD Namlea namun PLN tetap harus memperhitungkan keuntungan ekonomis produksi energi listrik salah satunya biaya pokok produksi. Dengan demikian jenis bahan bakar yang terpilih haruslah jenis bahan bakar yang merupakan bagian dari bahan bakar baru terbarukan, tetap ekonomis, dan memberikan keuntungan untuk perusahaan. Berdasarkan uraian tersebut maka jenis bahan bakar yang harus dipilih untuk digunakan di PLTD Namlea adalah Bio Solar (B20) dengan penambahan Thermol D. Hal ini terlihat dari jumlah penurunan biaya pokok produksi energi listrik tiap-tiap kWh nya serta turunnya nilai yang harus ditanggung pemerintah untuk subsidi pembelian listrik pada masyarakat.

Bila dilihat dari segi performansi alternatif 4 dengan nilai 58.2249387440 jauh lebih unggul dibandingkan dengan alternatif lain. Terutama pada alternatif awal dengan nilai 52.4138998098. Ini artinya alternatif 4 memiliki kemampuan yang sangat bisa diandalkan dalam menjawab permasalahan pemilihan jenis bahan bakar terkait dengan aspek lingkungan maupun keekonomisannya dalam proses produksi energi listrik. 
Ditinjau dari Value nya pun, alternatif 4 lebih tinggi dari alternatif awal maupun alternatif lain yang diberikan. Selisih Value alternatif 4 dengan alternatif awal sebesar 0.13270657 . Pada akhirnya secara jelas terlihat bahwa alternatif 4 mampu memberikan keuntungan yang besar pada kondisi normal dengan penurunan biaya pokok produksi sebesar Rp 54 ,-- per kWh serta subsidi yang harus dikeluarkan pemerintah per kWh turun sebesar Rp 1.229,--

\section{KESIMPULAN DAN SARAN}

Berdasarkan hasil penelitian yang telah dilakukan penulis di PLTD Namlea, maka dapat ditarik beberapa kesimpulan sebagai berikut :

1. Alternatif pemilihan jenis bahan bakar yang akan digunakan pada PLTD Namlea dipilih berdasarkan alternatif yang memiliki nilai paling ekonomis serta memiliki dampak yang baik terhadap lingkungan. Sehingga dari pemilihan jenis bahan bakar ini biaya pokok produksi PLN bisa mengalami penurunan dan berdampak positif terhadap berkurangnya jumlah subsidi yang dikeluarkan pemerintah untuk pembelian energi listrik. Alternatif bahan bakar terpilih adalah alternatif ke 4 yaitu Penggunaan Bio Solar (B20) + Thermol D.

2. Dengan alternatif bahan bakar ke 4 biaya pokok produksi (BPP) mengalami penurunan. BBP ratarata alternatif bahan bakar ke 4 sebesar Rp. 2.695,93 sedangkan untuk alternatif awal BPP rata-rata sebesar Rp. 2.749,44. Dengan kata lain terdapat selisih BPP energi listrik PLN sebesar Rp. 54,- per kWh. Penghematan luar biasa yang dapat diperoleh PLN.

3. Disamping penurunan BPP, subsidi yang ditanggung oleh pemerintah juga menurun. Pada alternatif awal, biaya subsidi yang harus ditanggung pemerintah adalah Rp1.282,- per kWh. Sedangkan setelah alternatif bahan bakar ke 4 digunakan subsidi yang harus ditanggung pemerintah turun dengan nilai Rp. 1.229 ,- per kWh. Dengan demikian beban pemerintah terhadap pemenuhan subsidi pada sektor energi listrik berkurang.

4. Apabila dibandingkan dengan alternatif awal, performance pada alternatif bahan bakar ke 4 lebih tinggi yaitu 58.2249387440 dengan value 1.13270657 dibandingkan dengan alternatif awal dengan performansi sebesar 52.4138998098 dan value 1 . Hal ini menunjukkan bahwa dari sisi performansi dan nilai alternatif bahan bakar ke 4 jauh lebih unggul.

Berdasarkan hasil penelitian, maka penulis menyarankan beberapa hal yaitu:

1. Metode Value Engineering perlu diterapkan lebih awal dalam menganalisa suatu permasalahan pemilihan keputusan.

2. Untuk kedepannya kriteria ketersediaan pasokan bahan bakar bisa dimasukkan sebagai salah satu penilaian pemilihan penggunaan jenis bahan bakar di PLTD Namlea.

\section{DAFTAR PUSTAKA}

[1] Ardhita Hendriarto , Puji Saksono , Gunawan. Analisa Perbandingan Penggunaan Bahan Bakar Solar Dengan Biodiesel B10 Terhadap Performansi Engine Cummins QSK 45 C, Jurnal Teknologi Terpadu NO. 1 VOL. 4 Juni 2016 ISSN 2338 - 6649, Fakultas Teknologi Industri Universitas Balikpapan

[2] Camerling, Billy J. (2000). Penerapan Metode Rekayasa Nilai Pada Penentuan Peralatan Trawl Kapal. Tesis Magister Teknik pada ITS Surabaya.

[3] Johan F. Wattimury. (1998). "Penerapan Rekayasa Nilai (Value Engineering) Pada Mesin Induk Kapal, Tugas Akhir, Teknik Industri ITS Surabaya

[4] Heller, Edward. D. (1971). Value Management : Value Engineering and Cost Reduction. Pillipines : Wesley Publishing Company, Inc.

[5] Luqman Buchori, I. Istadi, P. Purwanto, Perkembangan Proses Produksi Biodiesel Sebagai Bahan Bakar Alternatif , Prosiding Seminar Nasional Teknik Kimia "Kejuangan" ISSN 1693-4393 Pengembangan Teknologi Kimia untuk Pengolahan Sumber Daya Alam Indonesia Yogyakarta, 18 Maret 2015

[6] Masbachul Ulum. (1996). Penerapan Rekayasa Nilai pada Perencanaan Lambung Kapal Nelayan. Tugas Akhir pada Teknik Industri ITS Surabaya.

[7] Muhamad As'adi, Kaji Eksperimental Keausan Komponen Mesin Diesel Berbahan Bakar Biodiesel dan Solar, Teknik Mesin. Universitas Pembangunan Nasional "Veteran" Jakarta, 2018, Documents Professional Platform - PDF Download Free, https://adoc.tips/

[8] Miles, Lawrence. D. (1972). Techniques of Value Engineering and Analysis (2nd ed.). New York : Mc Graw Hill Inc.

[9] Priyohadi Kuncahyo, Aguk Zuhdi M. Fathallah. (2014). Analisa Prediksi Potensi Bahan Baku Biodisel Sebagai Suplemen Bahan Bakar Motor Diesel di Indonesia, Jurnal Teknik POMITS Vol. 2, No. 1, (2014) ISSN: 2337-3539 (2301-9271 Print)

[10] Soni S. Wirawan, Armansyah H. Tambunan, Martin Djamin, Hiroshi Nabetani, dan Arief Sabdo Yuwono, Studi Efek Penggunaan Biodiesel Terhadap Emisi Pada Sektor Transportasi di Jakarta, Jurnal Teknik Lingkungan. Vol 9. No 2. Hal 211-219, Jakarta Mei 2008, ISSN 1441-318X, BPPT

[11] Thomas. L. Saaty (1976). Pengambilan Keputusan Bagi Para Pimpinan. Hal 85.

[12] Wiranto Arismunandar, Koichi Tsuda. (1986). Motor Diesel Putaran Tinggi. Jakarta : PT. Pradnya Paramita. 